\title{
Analytical study on the behavior of spirally welded steel columns
}

\author{
Bharathi K M* 1 , Jane Helena $\mathrm{H}^{\circledR 1}$ \\ 1 Department of Civil Engineering, College of Engineering Guindy, Anna University, Chennai, 600025 (India); \\ bharathi.structural@gmail.com; jane@annauniv.edu \\ *Correspondence: bharathi.structural@gmail.com
}

Received: 05.10.2020; Accepted: 14.10.2021; Published: 31.12.2021

Citation: Bharathi K M, and Jane Helena, H. (2021). Analytical study on the behavior of spirally welded steel columns. Revista de la Construcción. Journal of Construction, 20(3), 427-439. https://doi.org/10.7764/RDLC.20.3.427.

\begin{abstract}
Spirally welded tube (SWT) members are predominantly used for offshore oil and gas transportation in the pipeline industry. The use of SWTs in construction is gaining attention with emerging and qualitative research. SWT columns have no parametric limitation in manufacturing. However, no specific research is available for the influence of helix angle in SWT columns as structural member. This investigation stresses on understanding the behavior of SWT columns with different helix angles. Seventy-two finite element (FE) models of SWT columns have been analyzed to study the influence of length to diameter (L/D) ratio, diameter to thickness (D/t) ratio and helix angle on the load-carrying capacity. Test results of two SWT columns available in the literature are used for validating the developed FE model. In addition, the capacity of the columns based on standard codes is computed and compared with the FE results. All the columns are axially compressed and the buckling and post-buckling behavior are simulated. Initial stiffness and ductility index of the columns are discussed. Helix angle between $40^{\circ}$ to $50^{\circ}$ are found to show the best results.
\end{abstract}

Keywords: spirally welded column, finite element, non-linear, buckling, ductility.

\section{Introduction}

Steel structural members occupy an irreplaceable role in the construction industry. Any form of the structural member in steel provides enormous strength with the least occupying space. Another important factor is that steel does not produce any debris; everything is completely recyclable and reusable. Thin-walled SWT members are prominent due to the ease of fabrication. However, in thick-walled members, spiral welding does not contribute much (Aslani et al. 2015). SWTs are made by revolving the steel sheet with respect to a central axis at a particular angle. The length per revolution depends upon the angle of the helix. Stress during compression gets distributed in helical form ( $\mathrm{Li}$ et al. 2018). Figure 1 shows the general manufacturing of SWT. The SWTs are arc welded on both sides to maintain the continuity of material in the member. Long columns distribute the stress to attain equilibrium (Martínez, 2019).

Finite element modelling of concrete-filled SWT columns (Gunawardena and Aslani 2021a, 2021b, 2021c) states that FEM results are negligibly sensitive to the modelling of the spiral weld and shows equivalent behavior when the tubes are created as seamless circular tubes. There is a gap in understanding the behaviour of SWTs as structural members. In this investigation, the influence of the different helix angles on columns with similar dimensions, and similar helix angle for column with different dimensions have been studied. This study will bridge the gap in understanding sheet width and helix angle selection for fabricating SWT columns. 
Nomenclature

D - Diameter

$\mathrm{t}$ - thickness

$\mathrm{F}_{\mathrm{y}}-$ yield stress

$\mathrm{L}$ - length of column

$\mathrm{P}_{\mathrm{EXP}}$ - experimental load

PFEA - analytical load

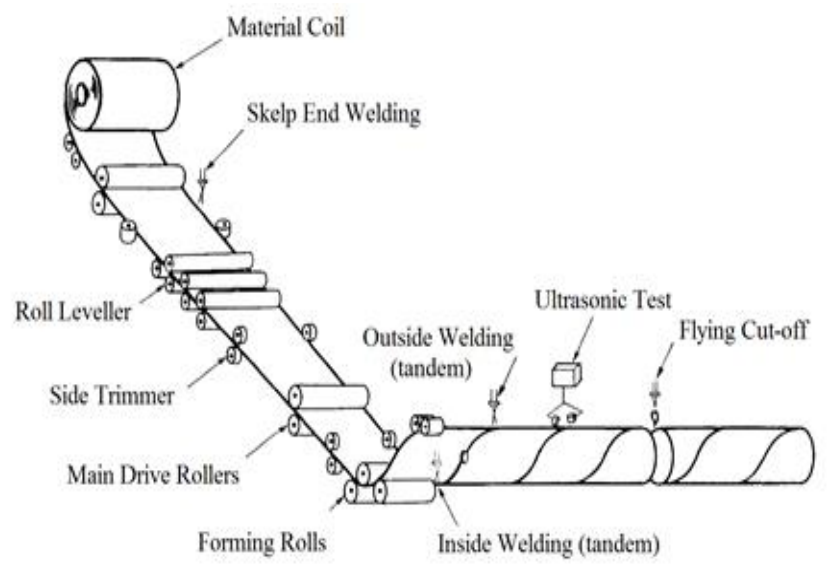

Figure 1. Manufacturing of SWT (Aslani et al., 2015).
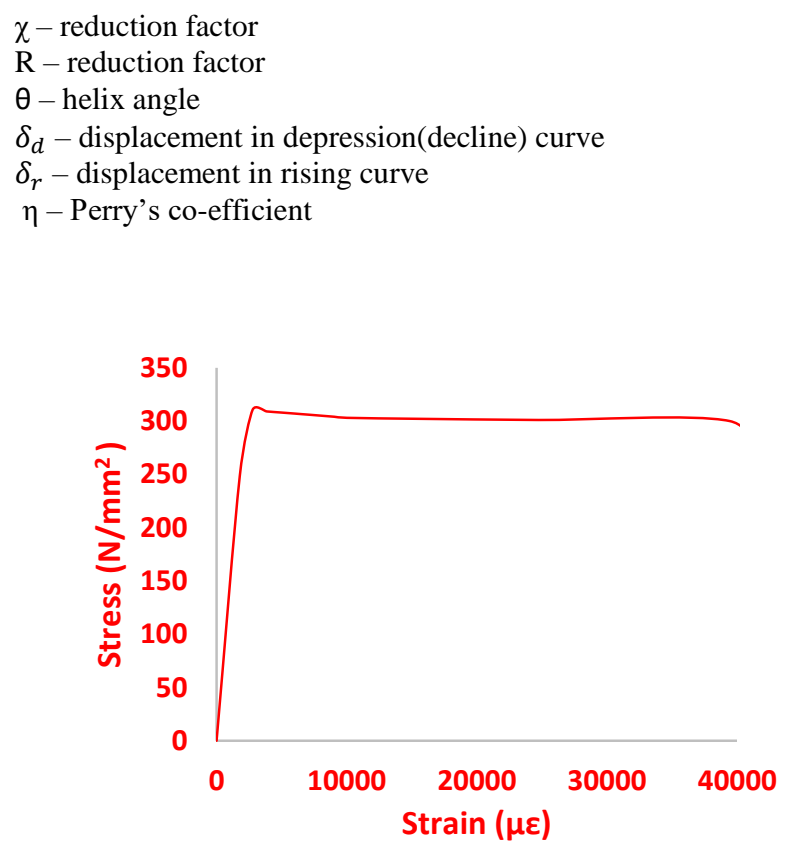

Figure 2. Stress-strain curve for adopted elastic-plastic behavior.

\section{Spirally welded column}

For the spirally welded (SW) columns used for analysis in this study, four different helix angles, $\theta$ (viz. $30^{\circ}, 40^{\circ}, 50^{\circ}$ and $60^{\circ}$ ) and nine different heights (viz. 600,750, 900, 1050, 1200, 1350, 1500, 1650 and 1800mm) were adopted. The helix angle $(\theta)$ is chosen such that the slope is neither large nor right-angled. Keeping the width of the sheet constant and varying the helix angle will result in increased weight and distortion of elements during loading with only a marginal increase in capacity due to the overlapping of sheets. Even a small distortion will become a weak point in the column, changing all the characteristics. There is a research gap in understanding the effect of helix angle in SWT as a structural member. In this study, SW columns of identical dimensions with different helix angle is addressed. Table 1 shows the details of sheet width required for each helix angle maintaining a constant number of pitches. Spirally welded steel columns can be produced continuously to any required dimensions and any wastage of material can be avoided.

Table 1. Details of sheet width.

\begin{tabular}{lllll}
\hline Helix angle $(\theta)$ & $30^{\circ}$ & $40^{\circ}$ & $50^{\circ}$ & $60^{\circ}$ \\
\hline Sheet width required $(\mathrm{mm})$ & 235 & 300 & 360 & 410 \\
\hline
\end{tabular}

\section{Codal provisions}

The use of SWTs in the pipeline industry goes a long way. There are provisions and tolerances for SW pipes specified by international standard codes. Limits for imperfection given in Bureau of Indian Standards (IS 5504, 1997), American Petroleum Institute (API 5L, 2013), International Organization for Standardization (ISO 3183, 2014)(supplements API 5L), Standards Australia (AS 1579, 2001), American Society for Testing and Materials (ASTM- A252, 2019) and European Standard (EN 10219- 2, 2019)(has the status of British Standard) are discussed in Table 2. The positive wall thickness tolerance does not apply to the weld area. The roundness and ovality tolerance is checked using the diameter and circumference. The length tolerance of API 5L is very flexible, whereas the weld bead height tolerance of AS 1579 is very stringent. These surface and dimension tolerances are also applicable for structural use. Existing standard codes such as Indian Standard (IS 801, 1998), 
British Standard (BS 5950- 5, 2006), American Standard (AISI S100, 2007), and European Standard (EC 3, 2011) accounts for the seamless and longitudinally welded tubular column. Among these, IS code uses the working stress method and the values are underestimated. This code is in the process of revision. The design equation for buckling resistance of SWT needs to be derived. European and American Standard codes use reduction factor $\chi$ and R respectively, which holds a value of $\leq 1$. British Standard uses Perry's co-efficient $(\eta)$ value $\leq 0.002$ < elastic stress value. But no code is available exclusively for the structural design of SWT column. The design equation for buckling resistance of SWT needs to be derived with tolerance and additional factors by considering the helix angle.

Table 2. Standard specifications and tolerances.

\begin{tabular}{|c|c|c|c|c|c|}
\hline Specifications & IS 5504, 1997 & $\begin{array}{c}\text { API 5L, } 2013 \\
\text { ISO 3183, } 2014\end{array}$ & $\begin{array}{l}\text { AS 1579, } \\
2001\end{array}$ & $\begin{array}{c}\text { ASTM A252, } \\
2019\end{array}$ & $\begin{array}{c}\text { BS EN 10219- 2, } \\
2019\end{array}$ \\
\hline $\begin{array}{l}\text { Wall thickness } \\
\text { tolerance }\end{array}$ & $\begin{array}{c}+15 \% \text { and } \\
-12.5 \%\end{array}$ & $\pm 1.5 \%$ to $\pm 10 \%$ & $\begin{array}{l} \pm 3 \% \text { to } \\
\pm 15 \%\end{array}$ & $\pm 12.5 \%$ & $\pm 10 \%$ \\
\hline $\begin{array}{l}\text { Imperfection } \\
\text { tolerance }\end{array}$ & $\leq 0.333 \mathrm{t}$ & $\leq 0.125 \mathrm{t}$ & - & $\leq 0.25 \mathrm{t}$ & Smooth surface \\
\hline Length tolerance & $2.5 \%$ & $\pm 500 \mathrm{~mm}$ & $\pm 7.5 \mathrm{~mm}$ & $\pm 25 \mathrm{~mm}$ & $2.5 \%$ \\
\hline $\begin{array}{c}\text { Straightness } \\
\text { tolerance }\end{array}$ & $\begin{array}{l}\text { Reasonably } \\
\text { straight }\end{array}$ & $\leq 0.2 \%$ & $\leq 0.2 \%$ & Reasonable & $\leq 0.2 \%$ \\
\hline $\begin{array}{l}\text { Weld bead height } \\
\text { tolerance }\end{array}$ & - & $\begin{array}{c}3.5 \mathrm{~mm} \text { to } 4.5 \\
\mathrm{~mm}\end{array}$ & $\begin{array}{l}1.5 \mathrm{~mm} \text { to } \\
3 \mathrm{~mm}\end{array}$ & - & $3.5 \mathrm{~mm}$ to $4.8 \mathrm{~mm}$ \\
\hline
\end{tabular}

\section{Finite element analysis (FEA)}

Finite element software is a real boon to save time and money, as experimental studies are very expensive. Finite element software (ABAQUS 6.13) has been used for this study. Any type of structure can be modeled and analyzed using discretized elements. For this current study, linear perturbation and non -linear Static Riks analysis have been carried out. Buckling mode imperfection is also incorporated in the model to account for the local buckling of the thin sheet. For accurate simulation of SWT, material properties such as Modulus of Elasticity, Poisson's ratio, stress and strain values for the elastic-plastic material constitutive model, considering von-Mises yield criterion were taken from (Aslani et al. 2017). Figure 2 shows the typical stress-strain curve adopted for the elastic-plastic material modelling. Isotropic material properties have been adopted for SWTs (Sadowski et al. 2015a).

\subsection{Mesh convergence study}

In finite element analysis for any member, a mesh sensitivity study is important to get reliable results. The sufficiently refined mesh ensures adequate simulation. As the number of element increases, the accuracy increases, at the same time, the computational time also increases. A mesh convergence study for a selected column is conducted with a coarser mesh size to a comparatively finer mesh size. For each mesh size, peak von-Mises stress is plotted as shown in Figure 3. As the mesh size gets finer, the number of elements increases and there is a surge in the stress. Likewise, with coarser mesh size, the elements are distorted from their isoparametric angle, increasing the stress. When the mesh refinement makes less than a $2 \%$ difference, the mesh is converged. It is seen that coarser mesh gives less accurate results, while the normal and finer mesh gives almost similar results. Also, when the mesh is very fine, it causes stress singularity resulting in non-converging infinite stress. In this study global mesh size of 10 is adopted for all the columns to get a stabilized solution. 


\subsection{Modelling, boundary condition and interaction}

Four node doubly curved shell element (S4R) having six Degrees of Freedom (DOF) at each node is used to model the SWT. The angle of mesh does not have a notable influence on the buckling load (Mahmoud et al. 2015). The weld is simulated using a solid element; by making the solid revolve with the required helix angle. Plate thickness is seen to be less at the coil edge (Van Es et al. 2013). At the region of welding, lumps are found in the SWTs, but these do not affect the geometry of the column (Sadowski et al. 2015b) . Each specimen is considered a perfect specimen and the dimensions are completely rounded for the initial stage. Linear perturbation buckling analysis and non-linear Static Riks analysis are carried out. Non-linear Static Riks analysis is capable of simulating the post-peak behavior. A rigid body tie constraint is adopted to make the analysis simpler without the endplates. One end of the column is fixed and the other end has a translational degree of freedom along the vertical axis alone. A uniformly distributed axial compressive load is provided to check the buckling modes and the least Eigenvalue is adopted as magnitude for the geometric non-linear analysis. The modeled column with different helix angles is shown in Figure 4.

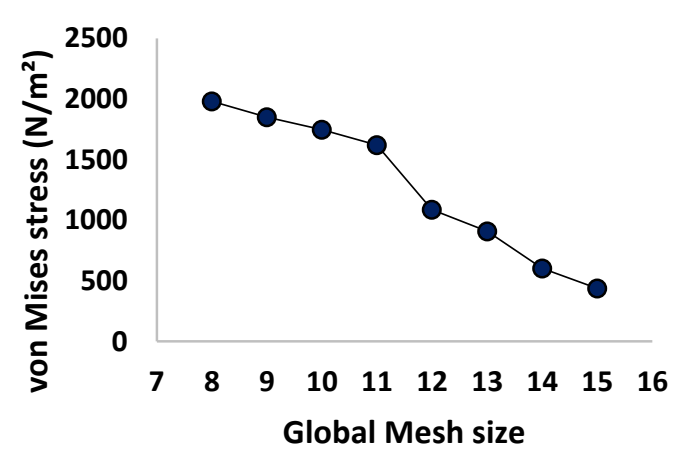

Figure 3. von Mises stress vs global mesh size. Figure 4. Typical columns with different helix angle.

\subsection{Validation}

To validate the developed FE model, the result of tests conducted by Aslani et al. 2017 is used. Two SWT columns, one short (HSWT102S) and one long (HSWT203L), were used for the comparison. The material properties and loading conditions were exactly incorporated in the FE model as presented in the literature. The experimental load value provided is compared with the FEA load values and is given in Table 3. The results show that the analytical values are in a close match with the experimental values. Table 4 shows the failure mode of the experimental models given by Aslani et al. 2017 and the failure mode obtained from the FE analysis. Figure 5 shows the load vs axial shortening plot. From these comparisons it can be seen that the FE model is capable of exactly simulating the actual behaviour of SWT columns irrespective of the slenderness ratio.

Table 3. Comparison between experimental and FE analytical load ratio.

\begin{tabular}{|c|c|c|c|c|c|c|c|c|c|}
\hline Specimen & $\begin{array}{l}\mathrm{L} \\
(\mathrm{mm})\end{array}$ & $\begin{array}{l}\mathrm{D} \\
(\mathrm{mm})\end{array}$ & $\mathrm{L} / \mathrm{D}$ & $\begin{array}{l}\mathrm{t} \\
(\mathrm{mm})\end{array}$ & $\mathrm{D} / \mathrm{t}$ & $\begin{array}{l}\mathrm{F}_{\mathrm{y}} \\
\left(\mathrm{N} / \mathrm{mm}^{2}\right)\end{array}$ & $\begin{array}{l}\text { Sheet width } \\
(\mathrm{mm})\end{array}$ & $\begin{array}{l}\text { PeXP } \\
(\mathrm{kN})\end{array}$ & $\frac{P_{E X P}}{P_{F E A}}$ \\
\hline HSWT102S & 300 & 103.5 & 2.89 & 1.9 & 54.2 & 288 & 260 & 183.26 & 1.03 \\
\hline HSWT203L & 1400 & 203 & 6.89 & 1.9 & 123.1 & 288 & 335 & 294.80 & 1.02 \\
\hline
\end{tabular}




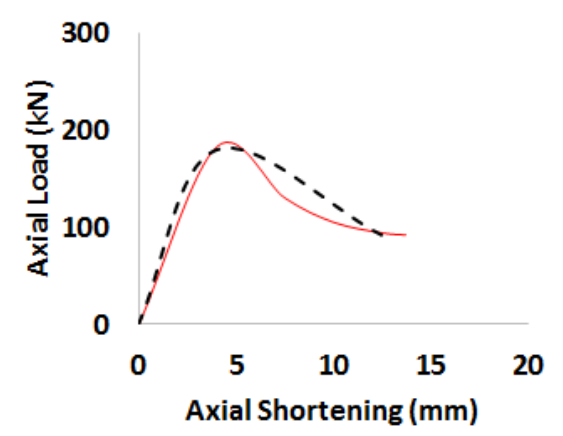

(a)

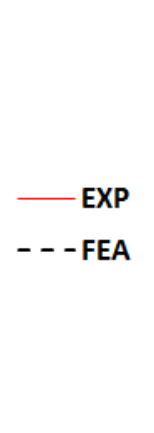

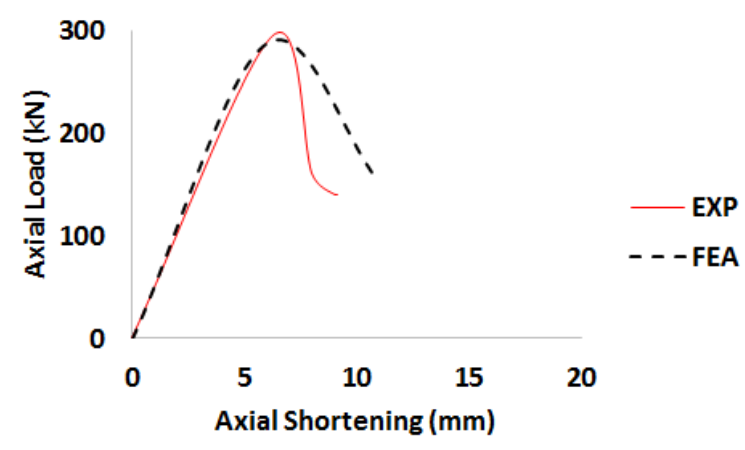

(b)

Figure 5. Axial load vs axial shortening (a) HSWT102S (b) HSWT203L.

Table 4. Experimental and analytical failure mode comparison.

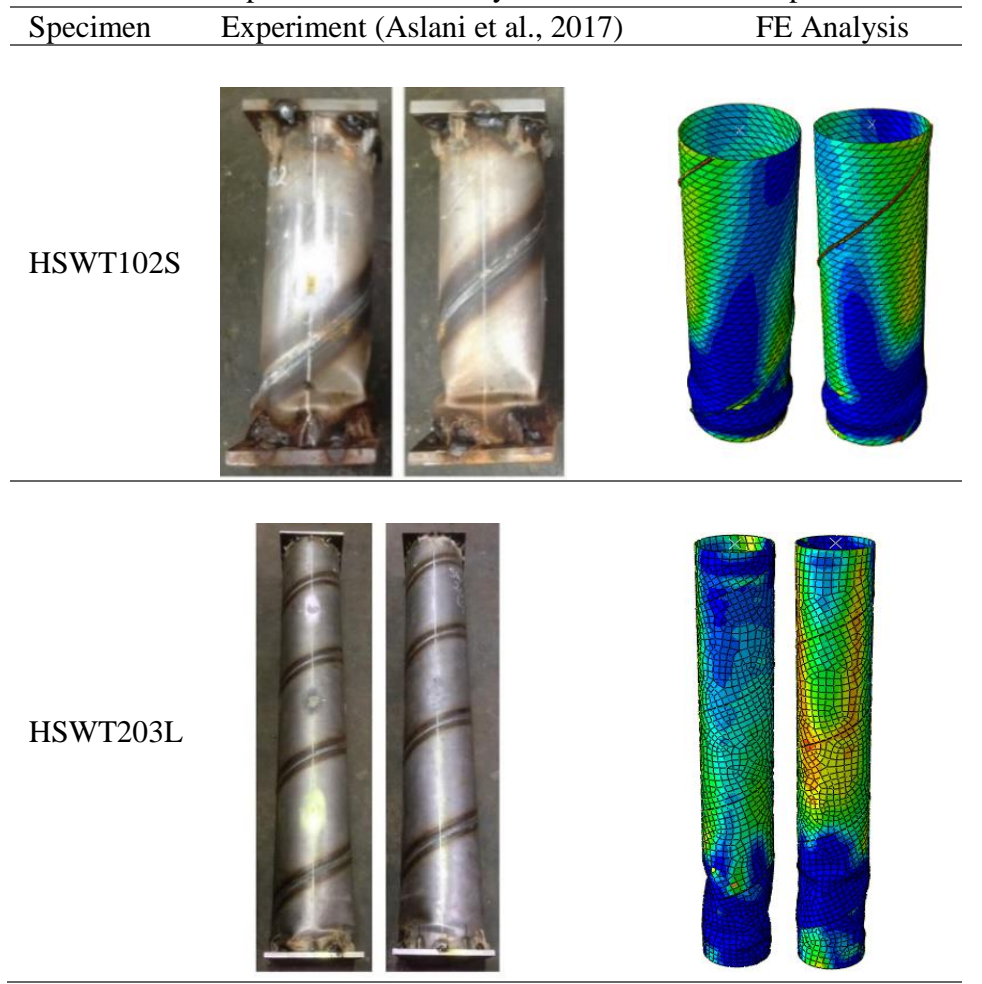

\subsection{Buckling and failure modes of columns}

The load values of FEA and the comparison with standard codes viz., Indian Standard (IS 801, 1998), British Standard (BS 5950- 5, 2006), American Standard (AISI S100, 2007), and European Standard (EC 3, 2011) are shown in Table 5. The load capacity is calculated using the standard equations for hollow steel columns. There is no specific code for SWT columns. The load values are calculated following the conventional column design. Among the codes referred, IS 801, 1998 follows the working stress method and the remaining follow the limit state method of design. Hence, the load values obtained are very conservative. Typical buckling mode shapes of the column are given in Figure 6. The columns failed by the radial expansion of tubes. The failure mode was notably seen when the column almost reached the ultimate load. The gap between FEA and codal design can be bridged by adding spiral co-efficient to the existing equations. 


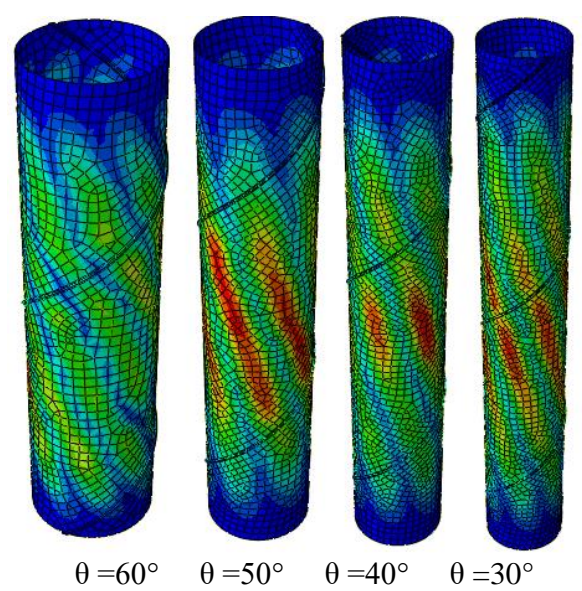

Figure 6. Typical buckling mode of SWT columns.

Table 5. Comparison between theoretical and analytical results.

\begin{tabular}{|c|c|c|c|c|c|c|c|c|c|c|c|}
\hline Specimen & $\theta$ & $\begin{array}{c}\mathrm{L} \\
(\mathrm{mm})\end{array}$ & $\begin{array}{l}\mathrm{D} \\
(\mathrm{mm})\end{array}$ & $\mathrm{L} / \mathrm{D}$ & $\begin{array}{c}\mathrm{t} \\
(\mathrm{mm})\end{array}$ & $\mathrm{D} / \mathrm{t}$ & $\begin{array}{l}\text { PFEA } \\
(\mathrm{kN})\end{array}$ & $\frac{P_{\text {FEA }}}{P_{\text {IS } 801}}$ & $\frac{P_{\text {FEA }}}{P_{\text {BS } 5950}}$ & $\frac{\mathbf{P}_{\mathrm{FEA}}}{\mathbf{P}_{\mathrm{EC} 3}}$ & $\frac{\mathbf{P}_{\mathrm{FEA}}}{\mathbf{P}_{\mathrm{AISI}, \mathbf{S 1 0 0}}}$ \\
\hline $2 P 1-600$ & \multirow{18}{*}{$30^{\circ}$} & 600 & 150 & 4 & 2 & 75 & 299.06 & 1.98 & 1.12 & 1.05 & 1.12 \\
\hline $2 \mathrm{P} 1-750$ & & 750 & 150 & 5 & 2 & 75 & 293.74 & 1.95 & 1.11 & 1.04 & 1.10 \\
\hline 2P1-900 & & 900 & 150 & 6 & 2 & 75 & 290.81 & 1.93 & 1.10 & 1.05 & 1.09 \\
\hline 2P1-1050 & & 1050 & 150 & 7 & 2 & 75 & 286.91 & 1.90 & 1.10 & 1.04 & 1.08 \\
\hline $2 \mathrm{P} 1-1200$ & & 1200 & 150 & 8 & 2 & 75 & 282.87 & 1.88 & 1.09 & 1.04 & 1.07 \\
\hline 2P1-1350 & & 1350 & 150 & 9 & 2 & 75 & 279.32 & 1.85 & 1.09 & 1.04 & 1.06 \\
\hline 2P1-1500 & & 1500 & 150 & 10 & 2 & 75 & 276.47 & 1.84 & 1.09 & 1.04 & 1.05 \\
\hline 2P1-1650 & & 1650 & 150 & 11 & 2 & 75 & 273.52 & 1.82 & 1.09 & 1.04 & 1.04 \\
\hline 2P1-1800 & & 1800 & 150 & 12 & 2 & 75 & 269.52 & 1.79 & 1.09 & 1.04 & 1.03 \\
\hline $3 P 1-600$ & & 600 & 150 & 4 & 3 & 50 & 490.84 & 2.93 & 1.11 & 1.04 & 1.11 \\
\hline $3 P 1-750$ & & 750 & 150 & 5 & 3 & 50 & 484.21 & 2.89 & 1.11 & 1.04 & 1.09 \\
\hline $3 P 1-900$ & & 900 & 150 & 6 & 3 & 50 & 480.53 & 2.87 & 1.11 & 1.05 & 1.09 \\
\hline 3P1-1050 & & 1050 & 150 & 7 & 3 & 50 & 474.90 & 2.84 & 1.10 & 1.05 & 1.08 \\
\hline 3P1-1200 & & 1200 & 150 & 8 & 3 & 50 & 467.19 & 2.79 & 1.10 & 1.04 & 1.07 \\
\hline 3P1-1350 & & 1350 & 150 & 9 & 3 & 50 & 460.56 & 2.76 & 1.09 & 1.04 & 1.05 \\
\hline 3P1-1500 & & 1500 & 150 & 10 & 3 & 50 & 455.20 & 2.72 & 1.09 & 1.04 & 1.05 \\
\hline $3 P 1-1650$ & & 1650 & 150 & 11 & 3 & 50 & 450.55 & 2.70 & 1.10 & 1.04 & 1.04 \\
\hline 3P1-1800 & & 1800 & 150 & 12 & 3 & 50 & 445.60 & 2.67 & 1.10 & 1.05 & 1.04 \\
\hline $2 \mathrm{P} 2-600$ & \multirow{8}{*}{$40^{\circ}$} & 600 & 150 & 4 & 2 & 75 & 298.95 & 1.98 & 1.12 & 1.05 & 1.12 \\
\hline $2 \mathrm{P} 2-750$ & & 750 & 150 & 5 & 2 & 75 & 291.89 & 1.94 & 1.10 & 1.04 & 1.09 \\
\hline 2P2-900 & & 900 & 150 & 6 & 2 & 75 & 290.82 & 1.93 & 1.10 & 1.05 & 1.09 \\
\hline $2 \mathrm{P} 2-1050$ & & 1050 & 150 & 7 & 2 & 75 & 286.97 & 1.91 & 1.10 & 1.04 & 1.08 \\
\hline 2P2-1200 & & 1200 & 150 & 8 & 2 & 75 & 282.86 & 1.88 & 1.09 & 1.04 & 1.07 \\
\hline $2 \mathrm{P} 2-1350$ & & 1350 & 150 & 9 & 2 & 75 & 279.75 & 1.86 & 1.09 & 1.04 & 1.06 \\
\hline 2P2-1500 & & 1500 & 150 & 10 & 2 & 75 & 276.56 & 1.84 & 1.09 & 1.04 & 1.05 \\
\hline $2 \mathrm{P} 2-1650$ & & 1650 & 150 & 11 & 2 & 75 & 273.44 & 1.82 & 1.09 & 1.04 & 1.04 \\
\hline
\end{tabular}




\begin{tabular}{|c|c|c|c|c|c|c|c|c|c|c|c|}
\hline 2P2-1800 & & 1800 & 150 & 12 & 2 & 75 & 269.55 & 1.79 & 1.09 & 1.04 & 1.03 \\
\hline $3 P 2-600$ & & 600 & 150 & 4 & 3 & 50 & 488.58 & 2.92 & 1.11 & 1.04 & 1.10 \\
\hline $3 P 2-750$ & & 750 & 150 & 5 & 3 & 50 & 484.64 & 2.90 & 1.11 & 1.04 & 1.09 \\
\hline $3 P 2-900$ & & 900 & 150 & 6 & 3 & 50 & 480.03 & 2.87 & 1.10 & 1.05 & 1.09 \\
\hline $3 \mathrm{P} 2-1050$ & & 1050 & 150 & 7 & 3 & 50 & 474.24 & 2.84 & 1.10 & 1.05 & 1.08 \\
\hline $3 \mathrm{P} 2-1200$ & & 1200 & 150 & 8 & 3 & 50 & 466.45 & 2.79 & 1.09 & 1.04 & 1.06 \\
\hline $3 \mathrm{P} 2-1350$ & & 1350 & 150 & 9 & 3 & 50 & 460.92 & 2.76 & 1.09 & 1.04 & 1.05 \\
\hline $3 \mathrm{P} 2-1500$ & & 1500 & 150 & 10 & 3 & 50 & 455.85 & 2.73 & 1.10 & 1.04 & 1.05 \\
\hline $3 \mathrm{P} 2-1650$ & & 1650 & 150 & 11 & 3 & 50 & 450.41 & 2.70 & 1.10 & 1.04 & 1.04 \\
\hline $3 \mathrm{P} 2-1800$ & & 1800 & 150 & 12 & 3 & 50 & 445.57 & 2.67 & 1.10 & 1.05 & 1.04 \\
\hline $2 \mathrm{P} 3-600$ & \multirow{18}{*}{$50^{\circ}$} & 600 & 150 & 4 & 2 & 75 & 298.84 & 1.98 & 1.12 & 1.05 & 1.11 \\
\hline $2 \mathrm{P} 3-750$ & & 750 & 150 & 5 & 2 & 75 & 291.76 & 1.94 & 1.10 & 1.04 & 1.09 \\
\hline 2P3-900 & & 900 & 150 & 6 & 2 & 75 & 291 & 1.93 & 1.11 & 1.05 & 1.09 \\
\hline 2P3-1050 & & 1050 & 150 & 7 & 2 & 75 & 286.61 & 1.90 & 1.10 & 1.04 & 1.08 \\
\hline 2P3-1200 & & 1200 & 150 & 8 & 2 & 75 & 282.77 & 1.88 & 1.09 & 1.04 & 1.07 \\
\hline 2P3-1350 & & 1350 & 150 & 9 & 2 & 75 & 279.65 & 1.86 & 1.09 & 1.04 & 1.06 \\
\hline $2 \mathrm{P} 3-1500$ & & 1500 & 150 & 10 & 2 & 75 & 276.05 & 1.83 & 1.09 & 1.04 & 1.05 \\
\hline $2 \mathrm{P} 3-1650$ & & 1650 & 150 & 11 & 2 & 75 & 273.71 & 1.82 & 1.09 & 1.04 & 1.04 \\
\hline 2P3-1800 & & 1800 & 150 & 12 & 2 & 75 & 269.40 & 1.79 & 1.09 & 1.04 & 1.03 \\
\hline $3 P 3-600$ & & 600 & 150 & 4 & 3 & 50 & 487.94 & 2.92 & 1.11 & 1.04 & 1.10 \\
\hline $3 P 3-750$ & & 750 & 150 & 5 & 3 & 50 & 483.65 & 2.89 & 1.10 & 1.04 & 1.09 \\
\hline $3 P 3-900$ & & 900 & 150 & 6 & 3 & 50 & 479.70 & 2.87 & 1.10 & 1.05 & 1.09 \\
\hline 3P3-1050 & & 1050 & 150 & 7 & 3 & 50 & 474.07 & 2.83 & 1.10 & 1.05 & 1.08 \\
\hline 3P3-1200 & & 1200 & 150 & 8 & 3 & 50 & 467 & 2.79 & 1.09 & 1.04 & 1.06 \\
\hline 3P3-1350 & & 1350 & 150 & 9 & 3 & 50 & 460.75 & 2.76 & 1.09 & 1.04 & 1.05 \\
\hline 3P3-1500 & & 1500 & 150 & 10 & 3 & 50 & 456.95 & 2.73 & 1.10 & 1.05 & 1.05 \\
\hline 3P3-1650 & & 1650 & 150 & 11 & 3 & 50 & 450.67 & 2.70 & 1.10 & 1.05 & 1.04 \\
\hline 3P3-1800 & & 1800 & 150 & 12 & 3 & 50 & 444.63 & 2.66 & 1.10 & 1.04 & 1.03 \\
\hline 2P4-600 & \multirow{13}{*}{$60^{\circ}$} & 600 & 150 & 4 & 2 & 75 & 298.79 & 1.98 & 1.12 & 1.05 & 1.11 \\
\hline 2P4-750 & & 750 & 150 & 5 & 2 & 75 & 291.64 & 1.94 & 1.10 & 1.04 & 1.09 \\
\hline 2P4-900 & & 900 & 150 & 6 & 2 & 75 & 290.43 & 1.93 & 1.10 & 1.04 & 1.09 \\
\hline 2P4-1050 & & 1050 & 150 & 7 & 2 & 75 & 286.46 & 1.90 & 1.10 & 1.04 & 1.08 \\
\hline 2P4-1200 & & 1200 & 150 & 8 & 2 & 75 & 282.55 & 1.88 & 1.09 & 1.04 & 1.06 \\
\hline 2P4-1350 & & 1350 & 150 & 9 & 2 & 75 & 279.46 & 1.86 & 1.09 & 1.04 & 1.06 \\
\hline 2P4-1500 & & 1500 & 150 & 10 & 2 & 75 & 276.48 & 1.84 & 1.09 & 1.04 & 1.05 \\
\hline 2P4-1650 & & 1650 & 150 & 11 & 2 & 75 & 273.45 & 1.82 & 1.09 & 1.04 & 1.04 \\
\hline 2P4-1800 & & 1800 & 150 & 12 & 2 & 75 & 269.73 & 1.79 & 1.09 & 1.04 & 1.03 \\
\hline $3 \mathrm{P} 4-600$ & & 600 & 150 & 4 & 3 & 50 & 484.84 & 2.90 & 1.10 & 1.03 & 1.09 \\
\hline $3 \mathrm{P} 4-750$ & & 750 & 150 & 5 & 3 & 50 & 483.48 & 2.89 & 1.10 & 1.04 & 1.09 \\
\hline $3 P 4-900$ & & 900 & 150 & 6 & 3 & 50 & 478.84 & 2.86 & 1.10 & 1.04 & 1.08 \\
\hline 3P4-1050 & & 1050 & 150 & 7 & 3 & 50 & 473.75 & 2.83 & 1.10 & 1.05 & 1.08 \\
\hline
\end{tabular}




\begin{tabular}{|c|c|c|c|c|c|c|c|c|c|c|}
\hline 3P4-1200 & 1200 & 150 & 8 & 3 & 50 & 466.76 & 2.79 & 1.09 & 1.04 & 1.06 \\
\hline $3 \mathrm{P} 4-1350$ & 1350 & 150 & 9 & 3 & 50 & 460.63 & 2.76 & 1.09 & 1.04 & 1.05 \\
\hline 3P4-1500 & 1500 & 150 & 10 & 3 & 50 & 455.77 & 2.73 & 1.10 & 1.04 & 1.05 \\
\hline $3 \mathrm{P} 4-1650$ & 1650 & 150 & 11 & 3 & 50 & 450.33 & 2.70 & 1.10 & 1.04 & 1.04 \\
\hline 3P4-1800 & 1800 & 150 & 12 & 3 & 50 & 445.55 & 2.67 & 1.10 & 1.05 & 1.04 \\
\hline
\end{tabular}

\section{Results and discussion}

\subsection{Influence of $L / D$ ratio}

The load vs. axial shortening behavior is plotted for all the analyzed columns. The characteristics are shown in Figure 7. The load-carrying capacity of the column is not influenced by helix angle with a deviation of only $1-2 \%$. The primary path is the same for all columns, irrespective of the helix angles. L/D ratio has been chosen consecutively and the margin of difference is nominal between the short and long columns. All the columns have failed due to local buckling. Having the higher axial shortening values, the length of slender columns before and after failure differed more. On attainment of the maximum capacity, stress reduces gradually, causing strain softening.

\subsection{Influence of helix angle}

An increase in helix angle does not appreciably improve the load-carrying capacity of the SWT columns. A similar helix angle adopted for a column with a different $\mathrm{D} / \mathrm{t}$ ratio shows greater variations in the capacity and failure modes. This strongly depicts that, for different cross-sectional dimensions, each column requires a unique helix angle. Figure 8 shows the ultimate load of all the columns plotted against helix angle. Helix angles between $30^{\circ}$ to $60^{\circ}$ are found to give consistent results irrespective of the slenderness ratio.

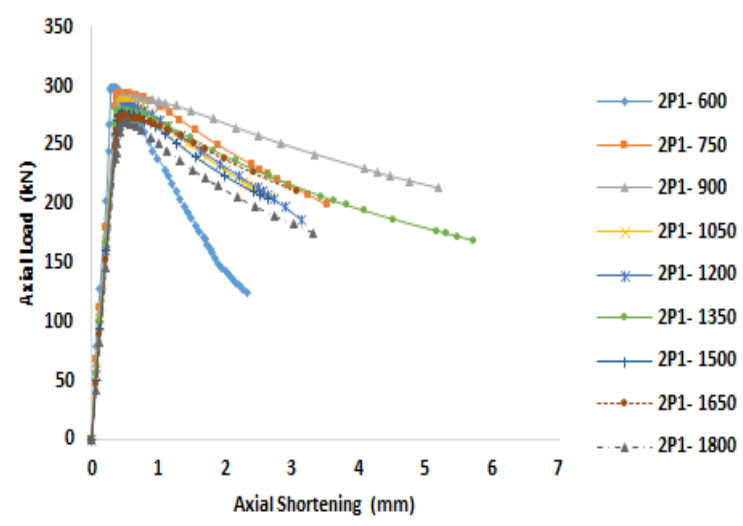

(a)

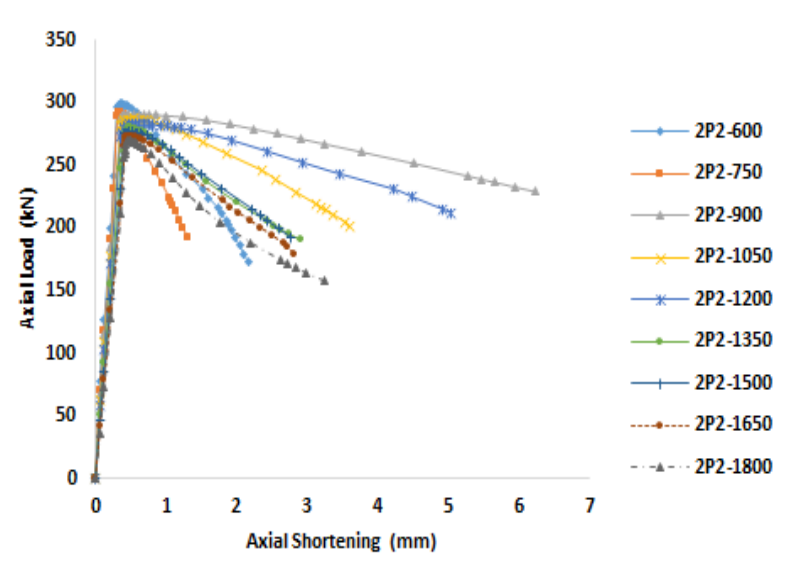

(b) 


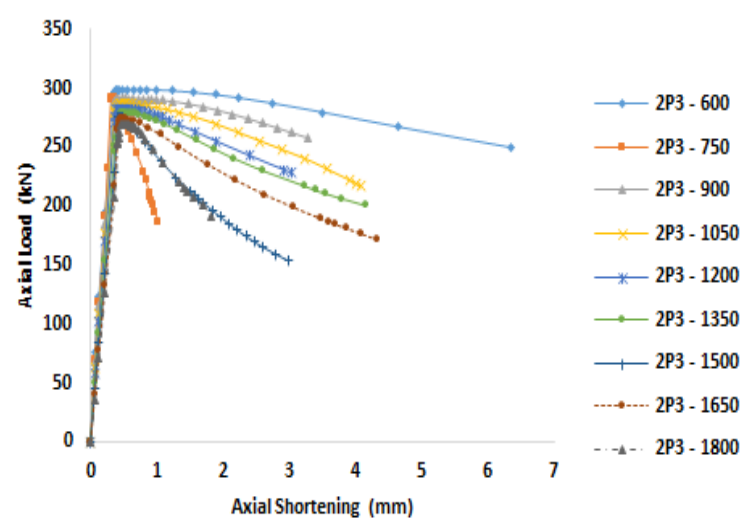

(c)

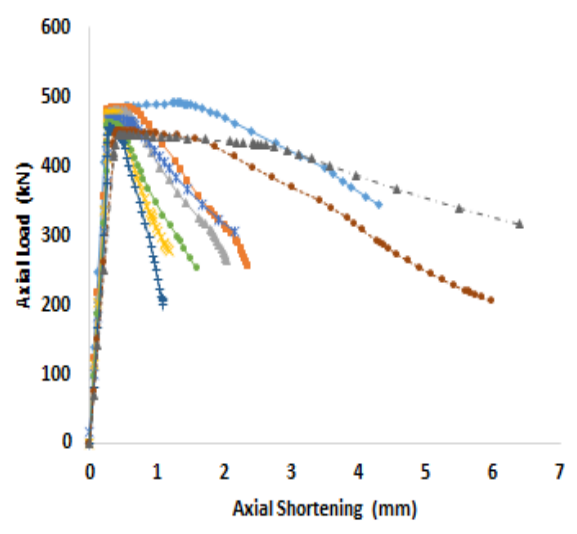

(e)

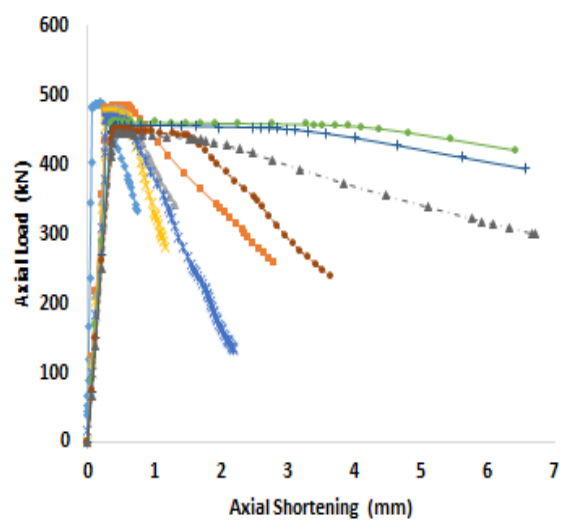

(g)

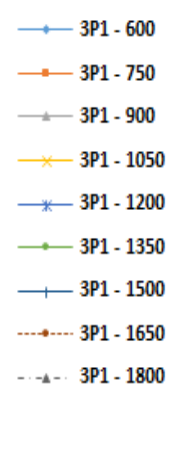

$\longrightarrow 3 P 3-600$

$=3$ P3. 750

$\longrightarrow 3 \mathrm{PP}-900$

- 3 P3 - 1050

- 3 P $3-1200$

$\longrightarrow 3 \mathrm{PP} 3-1350$

$\longrightarrow$ - 3 P $3-1500$

$\cdots$...... $3 P 3-1650$

- - - 3 3P3 - 1800

Figure 7. Axial load vs axial shortening (a) $2 \mathrm{P} 1$ columns (b) $2 \mathrm{P} 2$ columns (c) $2 \mathrm{P} 3$ columns (d) $2 \mathrm{P} 4$ columns (e) $3 \mathrm{P} 1$ columns (f) 3P2 columns (g) 3P3 columns (h) 3P4 columns. 


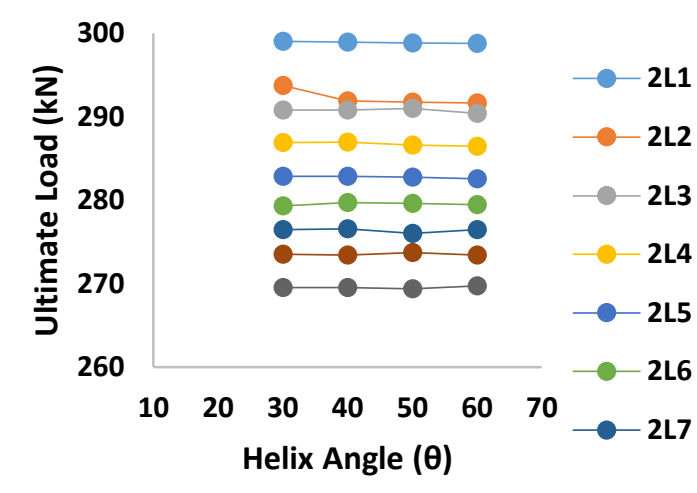

(a)

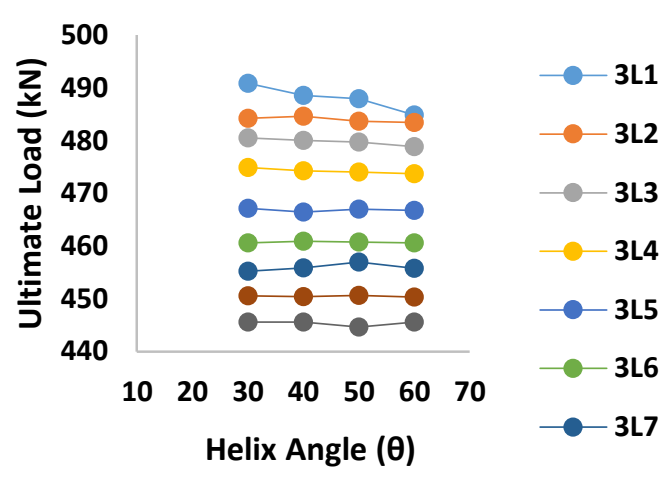

(b)

Figure 8. Ultimate load vs helix angle (a) $\mathrm{D} / \mathrm{t}=75$ (b) $\mathrm{D} / \mathrm{t}=50$.

\subsection{Influence of $D / t$ ratio}

An increase in D/t ratio from 50 to 75 decreases the strength capacity by 1.7 times for columns with the same L/D ratio and helix angle. Also, the decreasing scale of D/t ratio increases the ductile resistant characteristics of the member. Figure 9 shows the surface plot of load capacity with respect to helix angle and L/D ratio. Columns having D/t ratio of 75 show a narrow decline in the surface plot, while columns with $\mathrm{D} / \mathrm{t}$ ratio of 50 gradually spreads. The higher $\mathrm{D} / \mathrm{t}$ ratio significantly minimizes the effect of slenderness to decrease the capacity of columns. D/t ratio affects the failure by resisting the rupture of the wall and also has an effect on the stiffness, which clearly notifies that cross-sectional thickness has a considerable impact on the column.

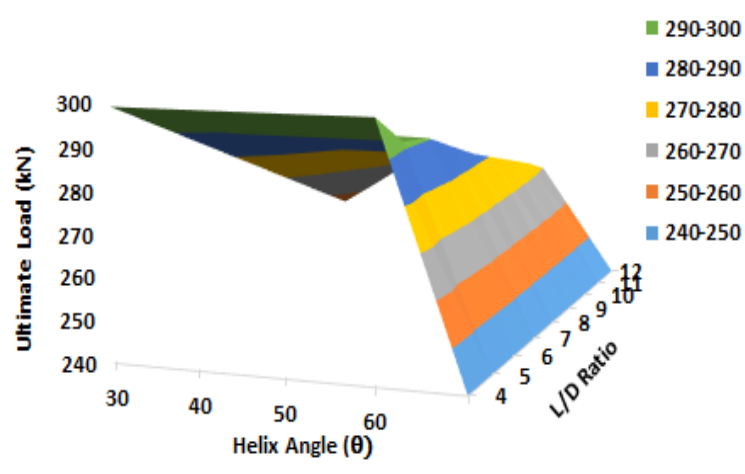

(a)

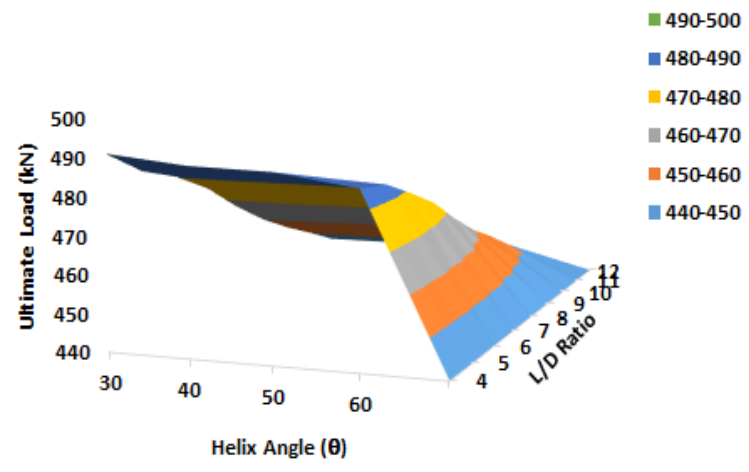

(b)

Figure 9. Ultimate load vs helix angle vs L/D ratio (a) $\mathrm{D} / \mathrm{t}=75$ (b) $\mathrm{D} / \mathrm{t}=50$.

\subsection{Initial stiffness and ductility index}

Average initial stiffness and ultimate load are plotted against the L/D ratio in Figure 10. Initial stiffness is calculated by taking the slope of load curve within the elastic limit. Initial stiffness is influenced by the L/D ratio. Ductility index decreases as the $\mathrm{D} / \mathrm{t}$ ratio increases (Gunawardena \& Aslani, 2018). The ductility index is calculated using equation (1) as proposed by Aslani et al. 2017. It is the difference between the column displacement in the rising and depression curve at $90 \%$ of the ultimate load. Figure 11 shows $\delta_{\mathrm{r}}$ and $\delta_{\mathrm{d}}$ position and ductility index variation. SWT columns show excellent ductility attributed by helix angle, which includes the unique spiral length of weld for each angle. 


$$
\text { Ductility Index }(\mu)=\frac{\delta_{\mathrm{d}}-\delta_{\mathrm{r}}}{\delta_{\mathrm{r}}}
$$
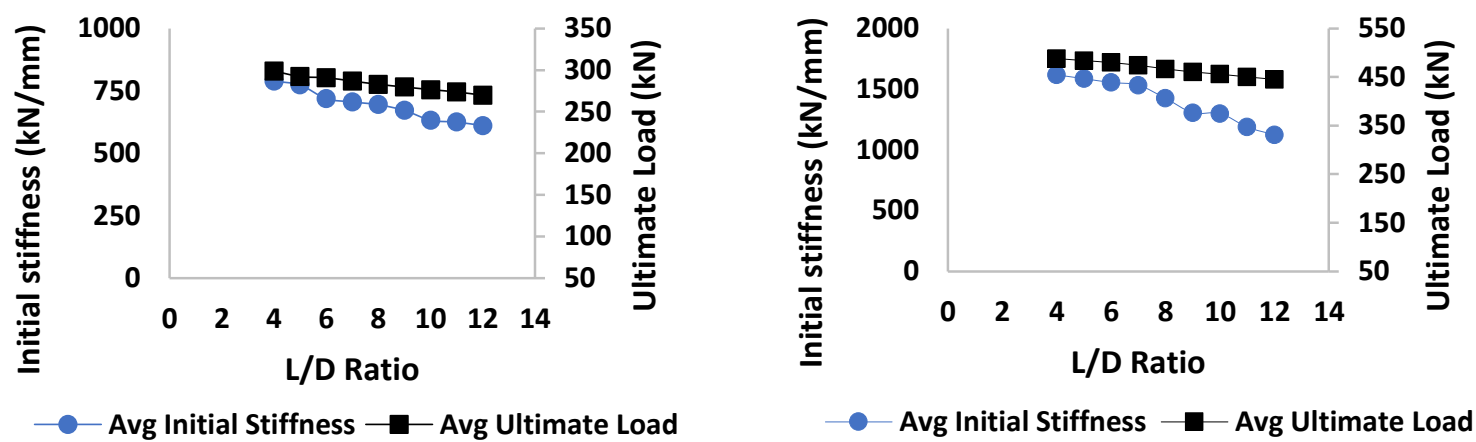

(a)

Figure 10. Initial stiffness (a) $D / t=75$ (b) $D / t=50$.

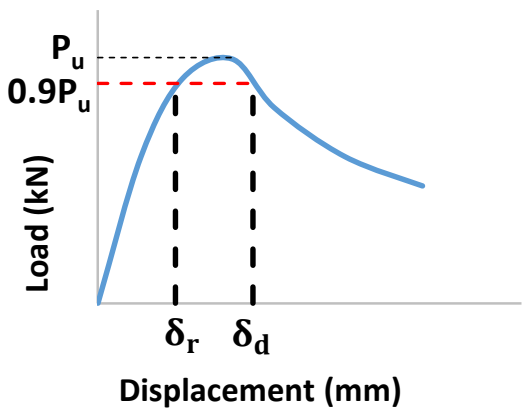

(a)

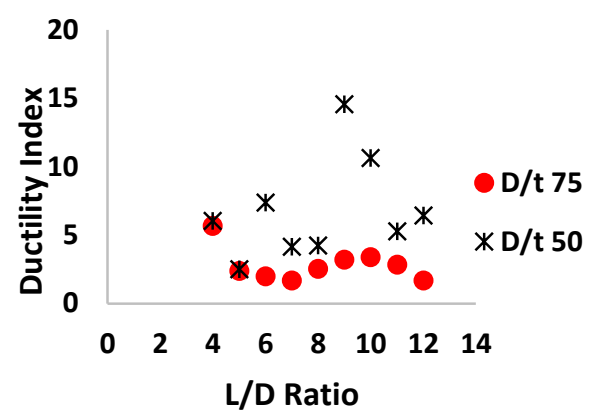

(b)

Figure 11. Ductility index (a) $\delta \mathrm{r}$ and $\delta d$ (b) D/t 75 and D/t 50 .

\section{Conclusions}

SWT is being used in many of the forums for making continuous tubes with a longer length. There is a gap in understanding the behavior of SWTs as structural members. Seventy-two columns of nine different L/D ratios and two D/t ratios are studied to understand the influence of the helix angle on the behavior of SWT columns. Four different helix angles have been chosen for the study. The analytical study concentrated on the capacity of the columns and their behavior. The codal specifications available for SWTs only address pipeline transportation purposes. No specific code is available for the SWT as a structural member. From this study, the following conclusions are drawn:

1. The weld does not cause failure in the columns.

2. The typical failure mode of the column is local buckling caused due to radial expansion of hollow tubes.

3. Short columns have a fine margin between different helix angles due to the lower distortional buckling than long columns.

4. Any width of strip material available can be adopted to fabricate the SWT columns. Also, material wastage can be avoided by using SWT columns.

5. The columns display high stiffness attributed to the helix angle.

6. Identical columns show better load, displacement, ductility and stiffness for helix angles $40^{\circ}$ and $50^{\circ}$. 
7. At present, there are no codal provisions that lay specifications on the behavior of SWTs used as structural members. There is a need to include correction factors based on helix angle in existing codal provisions for hollow steel tubes for predicting the behavior of SWT columns.

Authors' contributions: Conceptualization; BKM and JHH; Methodology; BKM and JHH; Numerical Investigation; BKM; Writing-Review and Editing, BKM and JHH; Supervision- JHH. All authors have read and agreed to the final version of the manuscript.

Conflicts of interest: The authors declare that there are no conflicts of interest regarding the publication of this paper.

References

ABAQUS 2013. Abaqus standard User’s manual, version 6.13, Dassault systemes. Abaqus User’s Guide.

AISI S100. (2007). North American Specification for the Design of Cold-Formed Steel Structural Members.

API 5L. (2013). Specification for Line Pipe, American petroleum institute, Washington DC. 45th Edition.

AS 1579. (2001). Australian Standard ${ }^{\mathrm{TM}}$ Arc-welded steel pipes and fittings for water and wastewater.

Aslani, F., Uy, B., Hicks, S., \& Kang, W.-H. (2015). Spiral welded tubes - imperfections, residual stresses, and buckling characteristics. Proceedings of the Eighth International Conference on Advances in Steel Structures, 21-24 July 2015, Lisbon, Portugal, (September). https://doi.org/10.13140/RG.2.1.1399.7927/2

Aslani, F., Uy, B., Hur, J., \& Carino, P. (2017). Behaviour and design of hollow and concrete-filled spiral welded steel tube columns subjected to axial compression. Journal of Constructional Steel Research, 128, 261-288. https://doi.org/10.1016/j.jcsr.2016.08.023

ASTM- A252. (2019). Standard Specification for Welded and Seamless Steel Pipe Piles. In Current. ASTM International, West Conshohocken, PA,. https://doi.org/10.1520/A0252-10.2

BS 5950 -5. (2006). Structural use of steelwork in building. Part 5, Code of practice for design of cold formed thin gauge sections. (January), 59.

EN 10219 -2. (2019). Cold formed welded structural hollow sections of non-alloy and fine grains.

EN 1993-1-1. (2011). Eurocode 3: Design of steel structures Part 1-1 General rules and rules for buildings.

Gunawardena, Y., \& Aslani, F. (2018). Behaviour and design of concrete-filled mild-steel spiral welded tube short columns under eccentric axial compression loading. Journal of Constructional Steel Research, 151, 146-173. https://doi.org/10.1016/j.jcsr.2018.09.018

Gunawardena, Y., \& Aslani, F. (2021a). Finite element modelling of concrete-filled spiral-welded mild-steel and stainless-steel tubes in flexure. Structures, 32(September 2020), 792-816. https://doi.org/10.1016/j.istruc.2021.03.056

Gunawardena, Y., \& Aslani, F. (2021b). Finite element modelling of concrete-filled spiral-welded mild-steel tube short and long columns. Structures, 30(August 2020), 1020-1041. https://doi.org/10.1016/j.istruc.2021.01.074

Gunawardena, Y., \& Aslani, F. (2021c). Finite element modelling of concrete-filled spiral-welded stainless-steel tube columns under concentric and eccentric axial loading. Structures, 33(October 2020), 1119-1143. https://doi.org/10.1016/j.istruc.2021.05.015

IS 5504. (1997). Indian standard specification for spiral welded pipes.

IS 801. (1998). Cold-Formed Light Gauge Steel Structural Members in General. Public Works.

ISO 3183. (2014). International Standard, Petroleum and natural gas industries - steel pipe for pipeline transportation systems.

Li, D., Uy, B., Aslani, F., \& Hou, C. (2018). Numerical analysis of concrete-filled spiral welded stainless steel tubes subjected to compression. (Asccs), 365371. https://doi.org/10.4995/asccs2018.2018.7200

Mahmoud, A., Torabian, S., Jay, A., Myers, A., Smith, E., \& Schafer, B. W. (2015). Modeling protocols for elastic buckling and collapse analysis of spirally welded circular hollow thin-walled sections. Structural Stability Research Council Annual Stability Conference 2015, SSRC 2015, (March), 611626. https://doi.org/10.13140/2.1.4893.7763

Martínez, M. M. (2019). Application of the beam method to structural calculation of the long cylindrical concrete shells in the work of Felix Candela. Revista de La Construccion, 18(1), 134-144. https://doi.org/10.7764/RDLC.18.1.134 
Sadowski, A. J., Michael Rotter, J., Reinke, T., \& Ummenhofer, T. (2015a). Analysis of variance of tensile tests from spiral welded carbon steel tubes. Construction and Building Materials, 75, 208-212. https://doi.org/10.1016/j.conbuildmat.2014.11.015

Sadowski, A. J., Van Es, S. H. J., Reinke, T., Michael Rotter, J., Nol Gresnigt, A. M., \& Ummenhofer, T. (2015b). Harmonic analysis of measured initial geometric imperfections in large spiral welded carbon steel tubes. Engineering Structures, 85, 234-248. https://doi.org/10.1016/j.engstruct.2014.12.033

Van Es, S., Gresnigt, A. M. (Nol), Kolstein, H., \& Bijlaard, F. S. K. (2013). Local Buckling of Spirally Welded Tubes - Analysis of Imperfections and Physical Testing. Proceedings of the International Offshore and Polar Engineering Conference.

(ब) $\odot \Theta$ ution-Noncommercial-No Derivatives 4.0 International License. 